\title{
Basic income and social democracy
}

\author{
Philippe Van Parijs \\ Hoover Chair of Economic and Social Ethics, University of Louvain, Belgium
}

in It's Basic Income: The Global Debate (Amy Downes and Stewart Lansley eds.), Bristol: Policy Press, 2018, 118-122.

'It is high time to make room for a third model of social protection fundamentally different both from the old social assistance model - public charity — and from the social insurance model worker solidarity - with which social democracy has been closely associated and which it feels it is its duty to defend.'

The idea of an unconditional basic income is in fashion. From Finland to Switzerland, from San Francisco to Seoul, people talk about it as they have never done. Twice before, basic income was the object of a real public debate, albeit briefly and limited to one country at a time. In both episodes, the centre left played a central role.

The first debate took place in England in the aftermath of World War I. The Quaker and engineer Dennis Milner managed to get his "state bonus" proposal discussed at the 1920 Labour Party conference. It was rejected, but prominent members of the party kept defending it in the following years under the label "social dividend". Among them were the Oxford economist and political theorist George Cole and the future Nobel laureate James Meade. ${ }^{1}$

The second debate took place in the United States in the late 1960s and early 1970s. Another future Nobel laureate, James Tobin, advocated the introduction of a "demogrant", along with Harvard economist and best-selling author John Kenneth Galbraith, also on the left of the Democratic Party. Persuaded by them, Senator George McGovern included the proposal in his programme during his campaign for the nomination as democratic presidential candidate, but dropped it in the last months before the 1972 presidential election which he lost to Richard Nixon.

The current, far longer and increasingly global debate originates in Europe in the 1980s. Interest for basic income arose more or less simultaneously in several countries and prompted the creation of a network (BIEN) that now has national branches in all continents. This time, however, the social-democratic left is not exactly at the forefront, far less than the greens, for example, or than some components of the liberal right and the far left .

What is there in basic income that can trigger the suspicion of social democrats and what is there in it that should prompt its enthusiasm? In order to answer such questions, it is important to clarify what a basic income is and what it is not.

A basic income is an income that is unconditional in three senses in which existing minimum income schemes are also unconditional: it is paid in cash, entitlement is not conditional on having paid social security contributions, and it is not restricted to citizens. It is also unconditional in three additional senses. It is individual, i.e. independent of its beneficiaries' household situation. It is universal, i.e. entitlement to it is not dependent on the level of their income from other sources. And it is duty-free, i.e. not restricted to those working or willing to work.

Is it not absurd to pay such a basic income to all, including the rich? It is not. The absence of an income test is not better for the rich. It is better for the poor. True, the rich do not need a basic income, just as they do not need to have the lowest layers of their incomes untaxed or 
taxed at low rates, as they do under current personal income tax systems. High earners will of course pay for their own basic income and for part of the basic incomes paid to others. One great advantage of an income paid automatically to all, irrespective of income, is that it reaches the poor far more effectively than a means-tested scheme, and without stigmatization. Another is that it provides them with a floor on which they can stand, because it can be combined with earnings, rather than a net in which they can easily get stuck because it is withdrawn if poor people start earning.

Is it not unacceptable to replace the right to a job by a right to an income? A basic income does nothing of the sort. On the contrary. It provides a flexible, intelligent form of job sharing. It makes it easier for people who work too much to reduce their working time or take a career break. It enables the jobless to pick up the employment thereby freed, the more easily as they can do so on a part-time basis, since their earnings are being added to their basic income. And the firm floor provided by the basic income makes for a more fluid back and forth between employment, training and family that should reduce the occurrence of burnout and early retirement, thus enabling people to spread employment over a longer portion of their lives. As social democrats rightly emphasize, access to paid work is important for reasons that far from reduces to the income it gives access to. Those who advocate a basic income paid without a work condition do not need to deny this. It is even taken for granted by those who are confident that a generous unconditional basic income is sustainable: despite a less miserable fallback option and higher taxation, people will keep working precisely because work means far more to them than just an income.

Does the introduction of a basic income not threaten the very existence of our welfare states? On the contrary, it comes to their rescue. Needless to say, a basic income is by no means an alternative to publicly funded education and health care. Nor is it meant to provide a full substitute to earnings-related social insurance benefits funded by workers' social contributions. Given that each household member will have his or her basic income, however, the levels of the cash benefits and the funding they require can be correspondingly reduced, the benefits individualized and simplified, and the depth of the traps associated with the conditions to which they are subjected will shrink.

Even in the longer run, social assistance cannot be expected to disappear either. Because of its being both individual and universal, sensible levels of basic income will not enable us to dispense with means-tested top ups for people in specific circumstances. Again, given the unconditional floor, traps will be reduced, the number of people dependent on these conditional benefits will shrink and the social workers' important job will be facilitated. Fitting an unconditional floor under the existing welfare state will not dismantle but strengthen our duly readjusted social insurance and social assistance schemes.

It is nonetheless true that a basic income constitutes a model of social protection fundamentally different from these existing two models. Consequently, one can expect people most closely involved in the pre-existing system to feel challenged and to oppose resistance. This was the case in the early $16^{\text {th }}$ century when municipal public assistance challenged the monopoly of Church-organized charity, and from the late 19th century when state-organized pension and health insurance systems challenged the position of poor relief institutions. It is not far-fetched to conjecture that the lack of enthusiasm for basic income among social democrats and in labour organizations has something to do with the important role they have been playing in initiating, developing and managing the social insurance schemes that now form the bulk of most of our welfare states.

Such resistance is perfectly understandable, indeed laudable: our social-insurance-based welfare states make a huge difference in terms of social justice and are therefore well worth defending. But this does not exempt social democrats from urgently updating their doctrine in order to better address the demands of our century: a century in which both the desirability and 
possibility of indefinite growth have lost for good the obviousness social democrats were banking on in the previous century, a century in which full-time life-long waged labour will only be possible and desirable for a minority, a century in which the left cannot let the right monopolize the theme of freedom.

As regards social protection, this requires making room for a third model fundamentally different both from the old social assistance model — public charity — and from the social insurance model - worker solidarity - with which social democracy has been closely associated and which it feels it is its duty to defend. In order to be able to address today's challenges, the left will need to move from "labourism" to "socialism", as it were, by getting rid of an illusion which has been at the core of much left-wing thinking ever since Marx's theory of exploitation. It needs to recognize fully that the bulk of our real incomes is not the fruit of the efforts of today's workers (let alone of the abstinence of today's capitalists), but a gift from nature increasingly combined with capital accumulation, technological innovation and institutional improvements inherited from the past. In a "labourist" perspective, those morally entitled to this gift - whether directly in the form of wages or indirectly in the form of social benefits to which they are entitled through their work - are the present generation of workers, in proportion to the market value of their skills, the length of their working time and their bargaining power. In a truly "socialist" perspective, those entitled to this gift are all members of society.

This more egalitarian, more emancipatory, less male-biased perspective entails a strong presumption in favour of an unconditional basic income. It is not something the left should be dreading. It is something it should enthusiastically embrace. ${ }^{3}$

This piece was originally published in Social Europe, April 2016.

\footnotetext{
${ }^{1}$ On the history of basic income proposals, see chapter 4 of P. Van Parijs \& Y. Vanderborght, Basic Income. A radical proposal for a free society and a sane economy, Harvard University Press, 2017.

3 Is there any indication that it will? Here is just one: 'The basic income approach is absolutely essential, but it is not part of the social democratic tradition. Think about it. The post-war consensus was all about national insurance, it was not about basic income. Now, either we are going to have a basic income that regulates this new society of ours, or we are going to have very substantial social conflicts.' (former Greek Finance Minister, Yanis Varoufakis, in The Economist, 31 March 2016). See chapter 7 of Van Parijs and Vanderborght, op.cit., for an overview of political support in the various political families.
} 